\title{
The Effect of Insecurity on Quality Tertiary Education in Nigeria
}

\author{
Paul Nwakpa \\ Department of Educational Foundations \\ Faculty of Education, Ebonyi State University \\ Abakaliki, Nigeria \\ Email: bropaulnwaoo [AT] gmail.com
}

\begin{abstract}
The study was conducted in Ebonyi State University, Abakaliki, to investigate the effect of insecurity on quality tertiary education in Nigeria. The purpose of the study was to investigate the effect of insecurity on quality of tertiary education and to evolve strategies to solve the problem the study was guided by four research questions. Descriptive survey research design was adopted. Five hundred respondents were used for the study. Questionnaire instrument was used to gather data for the study. Mean and standard were used to answer the research questions. The instrument was validated by 3 experts. The reliability index effects of the instrument was 0.78 the study found causes, of insecurity in tertiary educational institutions, and strategies to be employed. Finally, the study made some recommendations to include, full implementation of the suggested strategies.
\end{abstract}

Keywords--- Insecurity, Cultism, Sexual Harassment, Religious and Race Discrimination, Violence

\section{INTRODUCTION}

Matters of insecurity are topical issues in today's Nigeria education. Insecurity in tertiary institutions is a social problem that cannot be over-emphasized because of its far-reaching implications and dire consequences on education, the economy and society in general. It is an issue that should be seriously tackled as Nigerians endeavour to forge a strong, just, democratic and egalitarian society. Although the issue of insecurity has attracted much public interest over the years, interest in solving the insecurity equation appears to be waning and even when the issue is addressed, little emphasis seems to be paid on the gory socio-economic, political and spiritual implications. (Nnadi,2000).

On November 15, 1989, at the Awka Campus of former Anambra State University, gang warfare broke out between two cults; The Buccaneers and the Mgba Mgba Brothers who engaged in a fatal battle for supremacy with each other on the university campus. According to a report of the incident in Newswatch of March 12, 2000, during the cult war between the two groups; gun smoke choked the campus, driving students and lecturers into hiding. In the course of the fighting, a student in the department of Applied and Natural Sciences lost his life while another student was critically wounded as a result of stab wounds inflicted on him by errant cultists.

In a separate development, a lecturer in charge of verification of students' result in Rivers State University of Science and Technology reportedly had his office in the two-storey engineering complex in the university burnt by a cult group because he did not heed their warning earlier, to ensure that a member of their cult group did not fail his exams (Okafor \& Okafor, 2011).

An Optometry student of the University of Benin, who became a victim of campus insecurity, also recounted her gory story to Newswatch. She was going to class by 6am on a fateful day to catch up with some reading before the commencement of lectures, only to run into a convoy of cars carrying cultists all dressed in black; she was repeatedly raped by up to ten of the cult boys. (Newswatch, 12 March, 1990).

The ever present University of Abuja crisis also needs to be put to rest. No one is safe anymore. Parents who have their wards in schools feel very helpless knowing the safety of their children is not guaranteed.

In 2012, the same academic community was not isolated from the bombings and killings perpetuated by the Boko Haram: from the deadly attack on Bayero University Kano, on a Sunday morning when worshippers were attending service within the university's campus, to the bloody Independence Day attacks where more than 40 students of the Federal Polytechnic Mubi, were massacred. This is not counting the many isolated killing of students in broad daylight or at night when they were asleep and at their most vulnerable state. In some cases, just the rumour of an attack was enough to send some institutions packing, like University of Maiduguri and the Federal College of Education Potiskum, which had to start operating from the National Commission for Colleges of Education (NCCE) temporarily (Ajibade, 2013). 
These are just a few accounts of the gory tales of horror, terror and brutality unleashed in Nigeria's tertiary institution. The issue of the adopted Chibok Girls still on the news.

This paper shall attempt to explore the multi-faceted nature of campus insecurity, its dangers to the students, education and entire society, so as to proffer lasting solutions to insecurity in Nigeria tertiary education. In doing this, the researcher shall be relying on information/data gathered from previously published and unpublished research study/works and findings on the subject matter of insecurity on campus and other related subject matters, and researchers' own studies.

\section{Insecurity and Quality Tertiary Education: Ideological Interpretations}

Insecurity - the state of being subject to danger or injury, anxiety, fear, worry, uncertainty, unsureness. Best (2006) sees insecurity as a degenerated stage of conflict, threats to human security, intense violence characterized by fighting, death, injury, etc, occurs. To Olamosu (2000), insecurity is a state or condition in the life of a social unit, system, organization or society in which the existence of a; problem assumes critical dimension to the extent that the survival or existence of the social system or structure is threatened. The point here is that insecurity is a threat to the organization /society/system. However, in this paper, insecurity means a situation of sudden rampage in an organization/institution which necessitates making vital decision in the shortest time possible.

\section{What does Quality mean in the Context of Education?}

Many definitions of quality in education exist, testifying to the complexity and multifaceted nature of the concept. According to Bernard (1999) in all aspects of the school and its surrounding education community, the rights of the whole child, and all children, to survival, protection, development and participation are at the centre. This means that the focus is on learning which strengthens the capacities of children to act progressively on their own behalf through the acquisition of relevant knowledge, useful skills and appropriate attitudes; and which creates for children, and helps them create for themselves and others, places of safety, security and healthy interaction. However, quality education includes:

1. Learners who are healthy, well-nourished and ready to participate and learn, and supported in learning by their families and communities;

2. Environments that are healthy, safe, protective and gender-sensitive, and provide adequate resources and facilities;

3. Content that is reflected in relevant curricula and materials for the acquisition of basic skills, especially in the areas of literacy, numeracy and skills for life, and knowledge in such areas as gender, health, nutrition, HIV/AIDS prevention and peace;

4. Processes through which trained teachers use child-centred teaching approaches in wellmanaged classrooms and schools and skilful assessment to facilitate learning and reduce disparities;

5. Outcomes that encompass knowledge, skills and attitudes, and are linked to national goals for education and positive participation in society (UNESCO, 2000).

\section{Tertiary Education}

Nigeria is a federation of thirty-six (36) states and a Federal Capital Territory. The constitution of the Federal Republic of Nigeria identified a number of services on the concurrent list; services that both the federal and state governments can jointly perform with respect to governance. Education is one of the services on the concurrent list, apparently because it is an important, indispensable factor in development (Okafor and Okafor 2011).

Tertiary education is the third stage or level of education following the completion of secondary education. Federal Government of Nigeria (FGN) (1998) defines Tertiary Education to include the Universities, Polytechnics, Monotechnics and Colleges of Education in Higher Education.

Tertiary education generally culminates in the receipt of certificates, diplomas, or academic degrees emanating from rigorous training and imparting of knowledge in respective disciplines. Some of the goals of tertiary education as specified in National Policy on Education (2004) include:

1. To contribute to national development through high level manpower training.

2. To develop and inculcate proper value for the survival of society.

3. To acquire both physical and intellectual skills, which will enable individuals to be self reliant and useful members of the society?

4. To promote and encourage scholarship and community services.

No doubt, these lofty objectives cannot be realized in the face of incessant insecurity activities in Nigerian Tertiary Institutions. A quick glance at these objectives vis-a-vis corruption and poverty, cult activities, sexual harassment, examination malpractice in tertiary institutions clearly indicates that insecurity is inimical to the realization of the objectives of tertiary education. 


\section{REVIEW OF LITERATURE}

Corruption and Poverty have been identified as some of the challenges threatening security in Nigeria, This remark was made recently by Prof. M. A. Bidmos of the Department of Arts and Social Sciences Education, University of Lagos at the 2013 National Conference of Nigerian Universities Education Students' Association (NUESA) held at Tai Solarin University of Education, Ijagun. Prof. Bidmos attributed insecurity in Nigeria tertiary education to evils of corruption and poverty while noting that the country can only escape from this evil if Governments at all levels is committed to the discharge of their duties in order to better the welfare of its" citizens. The University dons admonished Nigerian students to break from the societal ills plaguing the nation and to equally desist from acts of violence in order for the country to take its rightful place in the comity of nations (Ajibade, 2013).

Two days of violence by students angry over fees issues at the University of Calabar wreaked unprecedented physical and psychological havoc. But in terms of the 25 -year-old law governing campus security, police posts are forbidden in universities and police may not enter campuses to help quell student riots. The institution's security personnel, despite being overpowered by the rampaging students, could get no assistance. Administrative blocks, the database room and the properties of academics had gone up in flames (Okafor and Okafor, 2011).

Meanwhile, the entire Nigerian university community was engulfed by fear and panic following an email allegedly sent by Islamic extremist group Boko Haram to the 15 universities in southern Nigeria. Public relations officer at the University of Benin, Harrison Osarenren, explained that the message was sent through an email address, bokoharamewe@yahoo.com, to the registrar. "They said that their aim was to eradicate Western education in Nigeria. This university has been shortlisted among 19 other universities. They warned that these universities will soon experience a series of bomb blasts," Osarenren reported in (Okafor and Okafor, 2011).

With the current insecurity in Nigerian higher education, President Goodluck Jonathan has .urged universities to bring their potentials to bear on solving contemporary problems facing the country. The President threw the challenge in a message to the 26th Convocation Ceremony of the University of Jos. The president reiterated: "our universities must align with our national goals and aspirations and brace up to the challenges of knowledge based competition. You must strive to be creative in your approach to contemporary problem solving, including the recurring insecurity problems in some parts of the country. For most other nations, higher education is today defining the pace of economic advancement, scientific progress, social development and national integration.

The goals of tertiary education as enunciated are crucial for national development. However, research by scholars such as Emaikwu and Eba (2001); Nwagwu (2005); and Okebukola (2006) have shown that many of the Nigerian tertiary educational institutions are finding it increasingly difficult to achieve the stated goals because of the problems confronting them. One of such is the problem of students' insecurity (Atteh, 1996; Onwurah, 2000; Alabi, 2002; Anifowoshe, 2004; Aluede, et al, 2005). Although Students' insecurity is a global phenomenon which has ravaged countries across the length and breath of the world, its occurrence in Nigeria in the recent past was on the high side.

Meanwhile, there are sources of factors to students' insecurity in Nigeria tertiary education. Onyenoru, (1996) stated that these are traceable to authoritarian governance arising from the erosion of institutional autonomy; infrastructural collapse and social distortion due to poor funding; poor motivation of staff who have a major obligation for the moral character and well-being of the students; the impact of the wider moral crisis on the tertiary institutions staff and students; and the precarious socio-psychological mental state of students as youths in social change and their consequent disposition to immediacy.

Some other scholars attributed insecurity in tertiary education as. declining economic conditions which have affected students* lives and studies, poor communication between institutions authorities and students, poor funding of tertiary institutions, insufficient and aging of social amenities and academic facilities, socialization influence, brain drain and poor attention to students; ideological and political reasons, etc (Ojo,1995; Olamosu, 2000; Salami, 2000; Ofordile, 2001; Agbola, et al, 2001; Aderinto, 2002; William, et al, 2003; Adisa, Okosi and Aderinto, 2004; Aluede, et al, 2005; Adeyemi, 2009).

Most of the heads of tertiary institutions in Nigeria adopt authoritarian/autocratic leadership style by not listening to the yearning and aspiration of the students, lazy in terms of provision of amenities such as water, health facilities, etc. These again act as strain on the students' actualization of their dream or goals which invariably result to crises situation in most of the tertiary institutions. For example, University of Abuja students demonstrated recently over non-provision of adequate laboratory for medical and engineering students, and thereby failing accreditation by the National Universities Commission (NUC) (Daily Trust, May 3, 2013).

Insecurity on campus negatively affects the learning process. It breeds fear and feelings of insecurity amongst students and staff of tertiary institutions and sometimes leads to disruption of the academic calendar. The impairment of learning on the campus threatens the development of the nation 
because no nation can rise beyond the capacities of her tertiary institutions. Moreover, cult clashes, often lead to wanton destruction of infrastructure and waste of resources. (Opaluwa, 2000). Moreso, members of secret cults risk losing their lives during the extremely dangerous and rigorous process of initiation or during intra and inter- cult clashes or face off with law enforcement agents; while the lives of people on campus and out of it are threatened by campus insecurity. The dangerous nature and far reaching implications of insecurity can be summarized in the very words of (Awe, 2001 in Okafor, and Okafor, 2011). Insecurity in the campus results to liberal consumption of alcohol, drug abuse, employ intimidation by threats, or use of violence, extortion, stealing, arson, armed robbery, sexual abuse, and rape, examination malpractice, fierce defence of what each opposition considers its domain of operation and maiming, manslaughter and murder.

Measures adopted by Authorities of Tertiary Institutions in Curbing Students insecurity: Scholars such as Ogunyemi (1994); Omole (1995); Onyenoru (1996) Onwurah (2000); Amadi, (2002), Alabi (2002) have written on the management of students" crises in Nigeria. According to these scholars, efforts at managing students' insecurity by the concerned authorities (government and institutions) often take the form of immediate closure of institutions with an ultimatum instructing students to vacate their halls of residence and premises; suspension or dissolution of students' unions and their executives. And when the crises have a national impact, the government often reacts by proscribing the Students Union Organization at the national level. Other strategies mentioned by these scholars include rustication or outright expulsion of student leaders and the use of security forces like the police/army to maintain law and order in the affected institution.

During General Ibrahim Babangida's Military Administration (1985-1993), the Students Union Activities (Control and Regulation) Decree No 47 was promulgated in 1989 which made national students union (NANS) and the unions in the respective universities subject to proscription if found to act contrary to national interest, security, public safety, morality and health. The decree also stipulated severe penalties for offenders including N500, 000 fines, or a five-year term of imprisonment, or both for persons convicted by the Special Tribunal set up under the decree (Onyenoru, 1996; Ogunyemi, 1994; Alabi, 2002). The Babangida administration also introduced voluntary unionism in the tertiary institutions which made it discretionary for students to belong to the students' unions- the National Association of Nigerian Students (NANS). That act was aimed at stifling the students' unions by reducing their membership and finances and frustrating their activities (Onyenoru, 1996).

Based on the forgone, this paper is poised in finding answers to the following questions (i) what are the factors responsible for students' insecurity in Nigerian tertiary educational institutions? (ii) What are the natures of the insecurity in Nigerian tertiary educational institutions? (iii) What are the effects of insecurity on quality education in Nigerian tertiary educational institutions? (iv) What are the alternative means of managing students' insecurity in Nigeria tertiary educational institutions?

In its issue of Sunday, July 7, 2013, the Sunday Mirror, a national newspaper in Nigeria, on its first page had a leading headline which screamed: "Horror in Yobe: 41 students, teacher roasted alive as Boko Haram sets hostel ablaze". On the same page of the same newspaper were other captions: Catalogue of Woes:

- 10 - year-old shot in the back

- 2 - year-old in the chest

- Father loses two sons

- Student had four fingers shot off

- Student's body burnt beyond recognition

Such horror experienced by a child in secondary school can shape the child's behaviour at the tertiary level of education and become a major psychological cause of insecurity by students.

\section{STATEMENT OF THE PROBLEM}

Nigerian tertiary educational institutions are established with the aim of giving any student who enrols a very sound and qualitative education^^ to be able to function effectively in any environment in which he/she may find him/herself; so as to become more productive, self-fulfilling and attain self actualization. It has been shown that many of the Nigerian tertiary educational institutions are finding it increasingly difficult to achieve the goals because of the problems of insecurity. However, it is obvious that the Nigerian economic and educational systems subject students to diverse strain and stress individually and as a group. For instance, many tertiary educational institutions in Nigeria lack basic amenities like functional laboratory, well equipped library, sports equipment and adequate hostel with functional facilities like water, light, etc, necessary for successful academic enterprises. Again, the spectre of unemployment, sexual harassment, cultism, underemployment and inflation haunts many students in Nigeria, Under this condition, students are apt to question and challenge the legitimacy of the social, economic, institutional 
and political arrangement producing such inimical conditions. Hence, the need for this study to find a veritable solution to the problem posed by insecurity to Nigeria's tertiary education.

\section{SIGNIFICANCE OF THE STUDY}

This paper is important because it will assist/help officers of both old and newly established tertiary institutions (both public and private) to have an in-depth understanding of insecurity phenomenon and its management in Nigeria. The prevalence of students' insecurity in Nigeria in the recent past makes the paper apt. This is because the more that is known of students' insecurity and its management, the better for the formulation of a realistic students insecurity management strategy that will help to achieve peace in tertiary institutions and, thus, contribute to the achievement of the goals of higher quality tertiary education as specified in the National Policy on Education.

\section{PURPOSE OF THE STUDY}

The purposes of the study were:

1. To investigate the factors responsible for students' insecurity in Nigerian tertiary educational institutions.

2. To find out the nature of insecurity in Nigerian tertiary educational institutions.

3. To examine the effects of insecurity on quality education in Nigerian tertiary educational institutions.

4. To proffer strategies for managing students insecurity in Nigerian tertiary educational institutions.

\section{RESEARCH QUESTIONS}

1. What are the factors responsible for students' insecurity in Nigerian tertiary educational institutions?

2. What is the nature of insecurity in Nigerian tertiary educational institutions?

3. What are the effects of insecurity on quality education in Nigerian tertiary educational institutions?

4. What are the strategies for managing students' insecurity in Nigerian tertiary educational institutions?

\section{METHODOLOGY}

The procedure adopted in collecting data for this research report was the descriptive survey design. The population was all staff and students of Ebonyi State University, Abakaliki, South East Nigeria, with a total of 3,500 staff and 8, 500 students.

Consequently, a sample size of 500 was taken from the population. Two strata were defined: staff and students. The simple random technique was applied to each stratum. While 350 students were sampled, 150 members of staff (teaching and non-teaching) were used for the study. A 42-item structured questionnaire (including biodata details) with Agreed (A) and Disagreed (D) options was used. The questionnaire had two parts A and B. Part A inquired into the respondents' personal information such as department, faculty, whether staff or student, level of study, number of years of service to the University and other issues. Section B used the agreed or disagreed options to enquire into the issues of insecurity, its causes, natures and consequences on quality education in tertiary institutions.

3 experts from Science Education Department of Ebonyi State University validated the instrument while the instruments reliability was obtained by pilot - testing using test-retest method and administered on a pilot group of 80 students of the Federal College of Education Obudu. A reliability coefficient of 0.78 was obtained and the instrument certified adequately reliable for the survey.

While staff were sampled in their offices (lecturers both in offices and meeting venues), students were met at sit-out venues like the gardens in the various faculties,

To avoid rejection of the questionnaire students were sensitized by some set of awareness creation before the administration of the instrument. It was observed that students showed lethargy apparently due to the large number of questionnaire they complete from researchers in the University community. Any explanations sought were promptly settled because the researcher of this work administered the instrument directly/personally with the assistance of ten research assistant.

The mean was the statistical tool used for the analysis. Any mean equal or above 2.50 was accepted while mean below 2.50 was disagree with. 


\section{ANALYSIS OF DATA}

\section{Table 1: Mean Responses on Causes of Students' Insecurity in Nigeria Tertiary Educational} Institutions. Lack of self confidence can lead persons into acts that can endanger other people's lives or cause fear

$3 \quad$ Frustration can lead a person into dangerous actions

$4 \quad$ Not admitting students into courses of their choice

$$
\mathrm{n}=500
$$

For Research Question 1, majority of the respondents agreed that students' insecurity is caused by multifaceted factors which include examination fever, lack of self confidence, frustration and not being admitted into a course of preference/choice. The mean is 3.31 which far exceed the minimum of 2.5. It can therefore, be safely concluded that insecurity from tertiary education students in Nigeria can be a result of the factors listed above. Viable solutions need to be sought to curb the situation.

Table 2: Mean Responses on the nature of students' insecurity in Nigerian Tertiary Education system

\begin{tabular}{|c|c|c|c|}
\hline No & Questionnaire items & $\overline{\mathbf{X}}$ & SD \\
\hline 5 & Intimidation of staff to get what a student wants & 3.33 & 1.82 \\
\hline 6 & Using cult to force an action from somebody & 3.08 & 1.90 \\
\hline 7 & $\begin{array}{l}\text { Sending parents, security operatives to force an underserved action from a } \\
\text { staff }\end{array}$ & 2.68 & 1.63 \\
\hline 8 & Disrupting/Preventing examination/test by force/violence & 3.96 & 2.00 \\
\hline 9 & Violent students' action to enforce a desire & 3.47 & 1.88 \\
\hline 10 & Luring staff to ward underserved marks or adjust exam scores & 3.30 & 1.89 \\
\hline 11 & Sexual harassment of female students by male lecturers & 3.84 & 1.04 \\
\hline \multirow[t]{3}{*}{12} & Nudity of female students in school environment & 3.78 & 1.88 \\
\hline & $\sum \mathrm{x}$ & 27.44 & 14.04 \\
\hline & $\mathrm{X}$ & 3.43 & 1.75 \\
\hline
\end{tabular}

The calculated mean for this research question is 3.43 while minimum mean is 2.5 and standard deviation is 1.75. This shows an overwhelming proof of what constitutes students' insecurity in Nigeria's tertiary education system. A further test was the computation of the standard deviation. Individual deviations from the mean were quite wide and the standard deviation of 14.04 shows that there is a great inclination towards the meaning and actions manifesting as insecurity by students.

Table 3: Mean Responses on the effects of students' insecurity in Tertiary institutions in Nigeria.

\begin{tabular}{|c|l|l|l|}
\hline No & Questionnaire items & $\overline{\mathbf{X}}$ & $\mathbf{S D}$ \\
\hline 13. & Insecurity makes education not to be of expected quality. & 3.56 & 1.56 \\
\hline 14. & Marks awarded under insecurity do not reflect student performance. & 3.33 & 1.82 \\
\hline 15. & Marks awarded by force is a cheating against other students & 3.52 & 1.84 \\
\hline 16. & $\begin{array}{l}\text { Unmerited graduation grade will lead to poor performance (of the } \\
\text { graduate) in the workplace. }\end{array}$ & 4.00 & 2.00 \\
\hline & $\sum \mathrm{x}$ & 1441 & 7.22 \\
\hline & $\mathrm{n}$ & 500 & 1.81 \\
\hline
\end{tabular}


The mean for agreed here is 3.60. Again it shows an over whelming acceptance of the hypothesis that insecurity affects quality education negatively. Lecturers are coerced to award underserved marks, students graduate with unmerited grade and the no- violent students are cheated. Education quality occurs under free operating environment and fair dealing. The graduates produced through insecurity end up not having the requisite knowledge and skill to operate in the workplace; they rather become a liability. The ultimate effect is poor performance of organizations and hence the national economy. This could be one of the greatest problems facing the Nigerian economy today since the incidences of insecurity in the educational system are quite high.

Table 4: Mean Responses on strategies for managing students' insecurity in Tertiary institutions in Nigeria.

\begin{tabular}{|c|l|l|l|}
\hline No & Questionnaire items & $\overline{\mathbf{X}}$ & SD \\
\hline 17. & Objectivity in the acquisition/giving of education & 3.84 & 1.87 \\
\hline 18. & Availability of necessary instructional materials/aids & 3.88 & 1.94 \\
\hline 19. & $\begin{array}{l}\text { Good background at the lower levels (primary secondary) of education } \\
\text { before sending outputs into tertiary education. }\end{array}$ & 3.92 & 2.00 \\
\hline 20. & Assurance of work/employment after graduation & 3.47 & 1.88 \\
\hline 21. & $\begin{array}{l}\text { Proper and regular guidance and counseling of students on various } \\
\text { programmes to desensitize them against actions inimical to quality } \\
\text { education. }\end{array}$ & 3.30 & 1.89 \\
\hline 22. & $\begin{array}{l}\text { Better funding of education by government and controlling of the excesses } \\
\text { of private operators in the sector. }\end{array}$ & 3.48 & 1.88 \\
\hline & \multicolumn{1}{|c|}{$\mathrm{n}$} & 21.89 & 11.46 \\
\hline & \multicolumn{1}{|c|}{$\mathrm{x}$} & 500 & 1.91 \\
\hline
\end{tabular}

RQ4 seeks to know the avenues for managing this insecurity.

Questionnaire items 17-22 addressed this. It identified issues such as avoidance of the following actions:

The six suggested strategies in table 4, all scored above mean value of 2.50. thus, they were all accepted as good strategies to solve the problem of students' insecurity in Nigerian tertiary educational institutions.

\section{CONCLUSION}

Developmental problem is not different from other socio-economic or socio-political problem be-deviling the Nigerian tertiary institutions. However, insecurity problem needs quick response, due to its significant effects on growth and development of our educational system. In promoting educational standard and sustainable development in tertiary institutions, federal and state governments and institution management should show more concern and interest in using their skillful and professional competence to bring about security and safety of the environment for the educational system to thrive.

\section{RECOMMENDATIONS}

It is therefore recommended here that the following actions should be taken:

1. Government should fund education properly and effectively monitor the activities of private operators in the education sector. A child who enter a tertiary education with very high scores obtained through fraud bur cannot perform in the higher institution will be frustrated and seek irregular means of passing.

2. There is need for proper and regular counseling of students and their parents/guardians to eschew fraud in education.

3. There is need for proper and regular training and retraining of teachers/lecturers on the rudiments of teaching not just lecturing.

4. There is need for counseling of teachers/lecturers on security, morality, professional ethics and good conduct in the educational system.

5. Most importantly, the suggested and accepted strategies in table should be adopted.

\section{REFERENCES}

- Aderinto, A. A. (2002). The Concept of Social Problem. In Isiugo-Abanihe U. C, Isamah, A. N. and Adesina J. O. (eds) Currents and Perspective in Sociology. Lagos: Malthouse Press.

- Adeyemi, T. O (2009) Causes, Consequences and Control of Students Crises in Public and Private Universities in Nigeria. Educational Research and Review, 4 (4). 156-163. 
- Adisa, J., Okosi A. \& Aderinto, A. (2004). Students' Unrest and University Governance in Nigeria: Causes, Patterns, Impacts and Prognosis. Research Report Submitted to the Social Science Council of Nigeria.

- Agbola, T., Olatubara, O, \& Alabi, M. (2001). Student On-Campus Housing at Bursting Point: A Case Study of the University of Ibadan, Ibadan: IFRA/African Builders.

- Ajibade, D. (2013). Students' Crisis in Nigerian Tertiary Institutions: A Review of the Causes and Management Style. Khazar Journal of Humanities and Social Sciences. 10 (5) 5-7.

- Alibi, A. O. Akanbi , G. O. \& Owoade, A. (2002). History of Education: A Course Test for the Undergraduates. Ibadan: Kingdave Publishers.

- Aluede, O., Jimoh, Agwinede, B. O., \& Omoregie, E. (2005). Student Unrest in Nigerian Universities: Looking Back and Forward. Journal of Social Science, 10 (1). 17-22.

- Anifowoshe, R. (2004) “Campus Violence: An Overview of Students' Protest in Nigeria's Tertiary Institution” In Lai Olurode and Omololu Soyombo (eds) Reading in Campus Violence. Lagos: Johnwest Publication Ltd.

- Atteh, S. O. (1996). The Crisis in Higheer Education in Africa. A Journal of Opinion (African Studies Association) 24 (1). 36-42.

- Awe, M. (2001). Paths to Peace, Stability and Sustainable Development in Nigerian Universities. The Nigerian Social Scientist 4 (1). 7-12.

- Bernard, A. (1999). The Child-Friendly School: a summary. Paper written for UNICEF New York.

- Best, S. G. (2006). The Method of Conflict Resolution and Transformation in Shedrack Gaya Best (ed) Introduction to Peace and Conflict Studies in West Africa. Ibadan: Spectrum Book Ltd.

- Daily Trust, April 3, 2012 (Abuja).

- Emaikwu, S; \& Eba, A (2001). Examination Malpractice in Tertiary Institution: Implication and the Way Forward. In Akubue, A. U. and Enyi, D (eds). Crises and Challenges in Higher Education in Developing Countries, Ibadan: Wisdom Publishers.

- Essien, A. (1990). Trouble in the Ivory Tower. Newswatch, March 12, pp. 14.

- Federal Government of Nigeria (2004) National Policy on Education (4th Edition). Yaba, Lagos: NERDC Press.

- Ngwana, A. S. (2003): Population and Development. Duala Cameroon African Development Corporation Ltd.

- Nnadi, A. (2000). Turning Point: An Authoritative and Practical Experience on eradication Campus Cults. Owerri: Encounter Communication.

- Nwagwu. N. A (2005). Crisis in the Nigerian Education System. A key not address, National Conference of the World Council for Curriculum and Institution at the University of Lagos.

- Ofordile, C. (2001). Crises and Challenges in Higher Education in Developing Countries, Students Factor: Cultism. In A.U. Akubue and D. Enyi (eds), Crises and Challenges in Higher Education in Developing Countries, A Book of Readings. Ibadan: Wisdom Publishers Ltd.

- Ogbumi, F. E. (2006). Understanding Why Education and Training Are Indispensable to Rapid Industrialization Achieving Rapid Industrialization and Democratization in Nigeria. 4, 1-120.

- Ogunyemi A (1994). Students' Unrest and University Governance under the Military: A case study Babangida Years, in Bello-Immam I. B. University Governance in Nigeria. Proceedings of the 8th General Assembly of the Social Science Council of Nigeria, Ibadan: The Social Science Council.

- Ojo, J. B. (1995). Students' unrest in Nigerian Universities: A Legal and Historical Approach. Ibadan: Spectrum and Institute for Research in Africa.

- Okafor, C. U. \& Okafor, J. A. (2011). Secret Cults in Tertiary Institutions in Nigeria, Nature and Dangers and the Way Forward. Journal of Research and Development, 2 (1). 22-26.

- Okebukola, P (2006). The State of Nigerian University. In Borishade, B and Okebukola, P (eds) Repositioning Higher Education in Nigeria. Ibadan: Heinemann Education Books (Nigeria) Plc.

- Olamosun, B (2000). Crisis of Education in Nigeria. Ibadan: Book Farm Publisher.

- Omole, P (1995) Managing Students' Crises in Nigerian Institution of Learning. In e. Okpema (ed) Education and Stability: A Book of Reading, Ibadan: Association for Promoting Quality Education in Nigeria.

- Opaluwa, A. (2000). Cultism and Nigeria campuses: The way out. Retrieved from www.gamji.com/article.

- $\quad$ Onyenoru, I.P. (1996). Nature and Management of Students' Conflict. Ibadan: Sociology Series No. 4, Department of Sociology, university of Ibadan.

- Onwurah, C.U (2000). Towards Effective Management of Students' Crises in Tertiary Institution. Nigerian Journal of Empirical Studies in Psychology and Education. 1 (2). 1-10. 
- Salami, A. A. (2004). Nigerian Student and Campus cults: Quest for Recognition. The Polymath, Journal of the Moshood Abiola Polytechnic, Abeokuta: 1(2). 75-87.

- Todaro, M. P. \& Smith, S.C. (2009). Economic Development (10 ${ }^{\text {th }}$ edition) England: Pearson Education Limited.

- UNICEF, (2000). Defining Quality in Education. A paper presented by UNICEF at the meeting of The International Working Group on Education Florence. Working Paper Series, Education Section, Programme Division. New York.

- William, S., Harnet, T., \& Strassner, E. (2003). Higher Education in Nigeria: A Status Report. Higher Education Policy, 16:259-281. 